\title{
AN ERROR ANALYSIS ON CHANGING ACTIVE VOICE INTO PASSIVE VOICE AT NINTH GRADE OF SMP AMIR HAMZAH MEDAN
}

\author{
Bambang Nur Alamsyah Lubis, Tazari Putri Afrilyani, Sri Wahyuni Girsang \\ Bintang Mangasih Tua Sihite, Shandy Chandra, Agus Permadi \\ Faculty of English Education \\ University of Prima Indonesia, Medan \\ Email: tazariputri@gmail.com, girsangyuni@gmail.com, bintangs223@gmail.com, \\ fairytales154@gmail.com, aghilkeyzeer@gmail.com
}

\begin{abstract}
This study focuses to analyze the errors probably make on changing active voice into passive voice. Was the study was conducted at SMP YPI Amir Hamzah Medan. The subject of the research was class VIII consisted of 24 students. The type of research is quantitative research. Based on the problem study aimed (1) to to identify and analyze the errors probably make on changing active voice into passive voice. (2) to find out the dominant tense has more errors on changing active voice into passive voice. The instruments of data collection is test. The data were obtained and used in quantative form. Based on data analysis, researchers found that the total errors made by students were 277 . The types of errors students made were ommission(56 or $20.22 \%$ ), misformation (168 or $60.65 \%)$, addition ( 28 or $10.11 \%$ ) and misordering ( 25 or $9.03 \%$ ). The data also shows that the dominant tense has more errorson changing active voice into passive voice is misformation.
\end{abstract}

Keywords: Washington Analysis, active voice and passive voice

\section{INTRODUCTION}

Language is a means of communicative. Language is an important role in human's life because it is the medium of communication, thought and learning. According to Brown (1999:5), "Language is a system of arbitary conventionalized vocal, written, gesture symbol that enable members of a given community to communicate intelligibly with one another". By using language, human can comunicate with other people to express the ideas, to facilitate the thinking process, and to recall the information. One of languages that has an important role in the world is English.

Nowadays the ability to use any foreign language is very important, especially when finding a good job. English is one of the foreign languages and an international language to master by people in order to get a job after graduating from college. English is using in science, technology, trade, politic and it used and learnt by many people all over the world. Indonesia itself, it cannot be denied to accelerate the mystery of the English language in order to make our country not to left behind from the other countries around the world in the science and technology development. There are four skills in English; speaking, reading comprehension, listening, and writing. These skills are importantly learned from the basic structure of the language.

Making errors is understandable for the students in learning second language. By realizing this errors, the learners get feedback of his acquisitions in learning process. It is quite possible for us to make errors in speaking, reading and writing English. Because the difference between the native language and the second language lies in pronunciation, vocabulary and grammatical structure.

In teaching grammar, passive voice is the one of the lessons that should be given more attention by the English teacher. It is important because passive voice is produced from active voice, so there are some ruler that must be explained on changing active into passive as clear as possible to the student.

On changing active voice into passive voices sometimes the students do not understand fully about rules of passive voice. It is quite possible for them to make errors. These errors should be corrected by them to avoid the students from creating the same errors.

On the other hand, the teacher sometimes forgets to correct the errors that students make. Where as, those errors will give feedback to the teacher in teaching grammar. It will give benefit to improve his technique of teaching grammar, especially passive voice.

So, by analyzing the student's errors on changing active into passive voice, the teacher will know which part of the syllabus need further attention to the text learning process and from those errors the students also get feedback in measuring how far their profiency dealing with passive voice. Literature Review

Grammar is a description of a language and the way in which units such as words and phrases are combined to produce sentences in the language. From this definition, it seems that grammar plays an important role in combining units of language to form sentences. The sentences are acceptable if they follow the rules of grammar. Since a communicative purpose and function of language are reflected in grammar, it is a must the language students to acquire good grammar. 
Active Voice

Active voice is stem from which the passive voice is produced. Basically in English there are only two voices namely active voice and passive voice. The active voice of the verb simply means the form of the verb used when the subject is the doer of the action. Many active voice sentences are transitive sentences. A transitive sentence is a sentence with a subject that performs the verbal action and an object that receives the verbal action.

The passive voice in general is formed by putting the verbs "to be" before the main verb, and the main verb of the active sentence must be changed into past participle.

Table 2.1 Active Voice Into Passive Voice

\begin{tabular}{|c|c|}
\hline Active & Passive \\
\hline The boy eats a bowl of soup & A bowl of soup was eaten by the boy \\
\hline Marry will drive the van & The van will be driven by Marry \\
\hline
\end{tabular}

Patricia and John (2007: 336) say that all verbs have active forms, but only transitive verbs (verbs that take an object) can appear in either the active or the passive voice. The voice (active or passive) does not normally affect meaning but it does change the focus of the sentence.

Table 2.2 Focus of Active Voice and Passive Voice in the Sentence

\begin{tabular}{|c|l|l|}
\hline Structure & \multicolumn{1}{|c|}{ Example } & \multicolumn{1}{c|}{ Focus } \\
\hline Active & $\begin{array}{l}\text { My dog bit the } \\
\text { Mailman }\end{array}$ & $\begin{array}{l}\text { In the active voice, the focus is on the agent } \\
\text { or the doer of the action (my dog). }\end{array}$ \\
\hline Passive & $\begin{array}{l}\text { The mailman was } \\
\text { bitten by my dog }\end{array}$ & $\begin{array}{l}\text { In the passive voice, the focus is shifted to } \\
\text { the receiver of the action (the mailman). }\end{array}$ \\
\hline
\end{tabular}

The Rules on Changing Active Voice Into Passive Voice, There are three rules we must be give pay attention on changing active voice to passive voice. Those are:

a. Move the direct object to the subject of the sentence

b. Move the subject in the last sentence and add preposition "by" before main verbs

c. Change the verb

Passive Voice in Many Tenses: Like an active voice, passive voice follow the tenses. Azar (2001) in the book "Fundamentals of English Grammar" gives the forms of the passive voices in various tenses as follows:

Table 2.3. The form of Passive Voice in Various Tenses

\begin{tabular}{|l|l|}
\hline \multicolumn{1}{|c|}{ Tense } & \multicolumn{1}{c|}{ Passive } \\
\hline Simple Present Tense & I am surprised by the news \\
\hline Present Continuous & $\begin{array}{l}\text { Some letters are being copied by the } \\
\text { secretary }\end{array}$ \\
\hline Simple Past Tense & I was surprised by the news \\
\hline Past Perfect & The letter had been mailed by Bob \\
\hline Future Tense & The letter will be mailed by Bob \\
\hline
\end{tabular}

The subject from active becomes the object when we change into passive voice as follows:

Table 2.4. The Subject From Active Into Passive Voice Become Object

\begin{tabular}{|c|c|}
\hline As Subject & As Object \\
\hline I & Me \\
\hline You & Your \\
\hline We & Us \\
\hline They & Them \\
\hline He & Him \\
\hline She & Her \\
\hline It & It \\
\hline
\end{tabular}

From the discussion above, it can be drawn the formula of the passive voice as follows:

$$
\text { S + auxiliary verb + past participle }
$$




\section{Error Analysis}

The discourse of error was carried by means of error analyses in the 1970s, error analyses supplanted contrastive analyses, which sought to predict the errors that learners make by identifying the linguistic differences between their LI (first language) and the target language.

Allwright and Bailey (2000 : 83) say that "Contrastive analyses (CA) is not an appropriate way in analyzing the errors. CA only concerns about differences and similarities". It can be said said that CA has limitation on analyze error in details, therefore, error analyses can replace to describe learners errors. Allwright and Bailey (2000 : 83) state, "Error Analyses differed from contrastive analyses in that it studied the errors actually made by the learners". As one of the first methods used analyze language learning, error analyses provides a methodology for investigate learner's language. For this reason, error analyses contributes an appropriate starting point for the study of learner Language and Acquisition.

\section{Mistake and Error}

Mistake and error as written by Corder as quoted by Dulay et al (1982 : 139) says that "In some of the second language literature, performance errors have been called "mistakes", while term "errors" was reserved for the systematic deviations due to the learners still developing knowledge of the L2 rule system". From the discussion above, it can be concluded that mistake refers to a performance that is either random guess or slip in that it is a failure to utilize a known system correctly but errors is competence.

\section{The Types of Error}

Based on surface strategy taxonomy, Dulay classify types of error, such as omission, addition, misformation, and misordering.

a. Omission

Omission errors are characterized by the absence of an item that must appear in the well-formed utterance.

b. Addition

For example omission of to be: Rendi the president of the company.

Addition errors are the opposite of omissions.

For example in syntax: The London

In morphology: The books is here

c. Misformation

Misformation errors are characterized by the use of the wrong form of the morpheme or structure.

For example: Rudi speaked English well.

d. $\quad$ Missordering

Missordering error occur because incorrect placement of a morpheme or a group of morphemes in an utterance.

For example: what Riki is doing?

Source of Error

Brown states four sources of error, they are: interlingual transfer, intralingual transfer, context of learning and communication strategies.

a. Interlingual Transfer

Interlingual Transfer is a significant source of error for all learners. Interlingual errors are the result of language transfer, which are caused by the learner"s first language

b. Intralingual Transfer

Intralingual transfer is the other reason for second language learner for committing errors. Intralingual errors result from faculty or partial learning of target language rather than language transfer. They may be caused by the influence of one target language upon another.

c. Context of learning

In the case of the school learning, context refers to the classroom with its teacher and material, and in the case of untutored second language learning, context refers to the social situation.

d. Communication strategies

Communication strategies were defined as related to learning style. Communication strategy relates to how people express meaning and deliver message to others. 
Step in Analyzing Error

According to Rod Ellis, the procedure for analyzing errors includes five steps, there are:

a. Collecting of a sample of learner"s language

Most samples of learner language which have been used in error analysis include data collected from many speakers who are responding to the same kind of task or test

b. Identification of Errors

The first step in the analysis requires determination of elements in the sample of learner language which deviate from the target L2 in some way.

c. Description of errors

The description of errors involves specifying how the forms by the learner differ from target form.

d. Explanation of errors

Accounting for why an error was made is the most important step in trying to understand the processes of SLA. Two of the most likely causes of L2 errors are interlingual and intralingual factors.

e. Evaluation of errors

There evaluation of errors includes the following steps:

1) Select the errors to be evaluated.

2) Decides the criterion on which the errors are to be judged.

3) Prepare the error evaluation instrument.

4) Choose the judges.

\section{RESEARCH METHOD}

This research uses descriptive qualitative research to collect the data.This research uses descriptive qualitative research to collect the data. According to Moleong (1995:02), in this research, the writer used the qualitative method, and the design of the research is case study. She analyzed and described the data from the observation by using qualitative method. Then, the writer analyzes the students error in changing active voice to passive voice, and to find out the type of errors, that the students made most in their test in changing active voice to passive voice, changing active sentence into passive sentence.

The subject of the research is the ninth grade students of SMP YPI AMIR HAMZAH Medan academic year 2019/2020. The ninth grade consists of two classes with the total 50 students, and the writer only took one class which consists of 24 students.

The instruments of the research tests. The writer gives the essay test as the instrument of the research. This test is focused on changing active voice to passive voice. The test consist of 20 questions.

\section{RESULT AND DISCUSSION}

Findings of the Reseacrh

Based on the analysis of changing active voice to passive voice on the 24 of students at the eighth grade SMP YPI Amir Hamzah Medan, it was found that there were many types of students' grammmarical errors in changing active voice to passive voice based on Surface Strategy Taxonomy Dulay (1982: 150). They were: Omissions, Additions, Misformations and Misordering types.

Table 4.1 Students' Grammatical Errors in Changing Active Voice to Passive Voice Based on Surface Strategy Taxonomy

\begin{tabular}{cccccccc}
\hline No & Students & OM & MF & MO & AD & $\begin{array}{c}\text { Total Number of } \\
\text { Errors }\end{array}$ & \% \\
\hline 1 & HFZ & - & 11 & - & 1 & 12 & 4,33 \\
\hline 2 & DSH & 2 & 2 & - & - & 4 & 1,44 \\
\hline 3 & WHY & 3 & 8 & - & 4 & 15 & 5,42 \\
\hline 4 & NYN & 2 & 5 & - & - & 7 & 2,53 \\
\hline 5 & ARN & 3 & 1 & - & - & 4 & 1,44 \\
\hline 6 & MIM & 4 & 2 & 3 & 1 & 10 & 3,61 \\
\hline 7 & MRD & 2 & 9 & 1 & - & 12 & 4,33 \\
\hline 8 & ASF & 3 & 6 & - & 1 & 10 & 3,61 \\
\hline
\end{tabular}




\begin{tabular}{|c|c|c|c|c|c|c|c|}
\hline 9 & DZR & 5 & 3 & - & & 8 & 2,89 \\
\hline 10 & MAR & 1 & 6 & - & 4 & 11 & 3,97 \\
\hline 11 & $\mathrm{ARG}$ & 3 & 7 & 1 & 1 & 12 & 4,33 \\
\hline 12 & ARJ & 3 & 7 & 1 & 1 & 12 & 4,33 \\
\hline 13 & $\mathrm{CHN}$ & 1 & 14 & 2 & 2 & 19 & 6,86 \\
\hline 14 & $\mathrm{MBN}$ & 3 & 9 & 1 & 2 & 15 & 5,42 \\
\hline 15 & ADL & - & 12 & 1 & 2 & 15 & 5,42 \\
\hline 16 & TSL & 4 & 4 & - & - & 8 & 2,89 \\
\hline 17 & SAL & 3 & 5 & - & 1 & 9 & 3,25 \\
\hline 18 & FUZ & 5 & 8 & 1 & 1 & 15 & 5,42 \\
\hline 19 & CTN & 1 & 8 & 1 & - & 10 & 3,61 \\
\hline 20 & ATY & 3 & 8 & 1 & 3 & 15 & 5,42 \\
\hline 21 & REZ & 3 & 8 & 1 & 3 & 15 & 5,42 \\
\hline 22 & $\mathrm{NBN}$ & - & 7 & 2 & - & 9 & 3,25 \\
\hline 23 & DAD & 2 & 9 & - & - & 11 & 3,97 \\
\hline 24 & NVR & - & 9 & 9 & 1 & 19 & 6,86 \\
\hline \multicolumn{2}{|c|}{ Total Errors } & 56 & 168 & 25 & 28 & 277 & 100 \\
\hline \multicolumn{3}{|c|}{$\begin{aligned} \text { Notes }: \mathrm{OM} & =\text { Ommission } \\
\mathrm{MF} & =\text { Misformation }\end{aligned}$} & & \multicolumn{3}{|c|}{$\begin{array}{l}\mathrm{MO}=\text { Misordering } \\
\mathrm{AD}=\text { Addition }\end{array}$} & \\
\hline
\end{tabular}

Based on the recapitulation of students' errors types in Table 4.1, total errors probably make on changing active voice into passive voice at the eighth grade of SMP YPI Amir Hamzah Medan is 277, they are : 168 errors in misformation, and 56 errors in omission, and 28 errors in addition, and 25 errors in misordering. the highest error of students' errors is miformation with the total errors 168. The lowest error of students' errors is misordering with the total errors 25 . Then, the writer calculated the frequency and the percentages of students' error types in the table below:

Table 4.2. Percentages of Kinds of Students' Errors

\begin{tabular}{cccc}
\hline No & Types Error & $\begin{array}{c}\text { Total Number } \\
\text { of Errors }\end{array}$ & $\mathbf{\%}$ \\
\hline 1. & Ommission & 56 & 20,22 \\
\hline 2. & Mis-formation & 168 & 60,65 \\
\hline 3. & Mis-ordering & 25 & 9,03 \\
\hline 4. & Addition & 28 & 10,11 \\
\hline Total & & $\mathbf{2 7 7}$ & $\mathbf{1 0 0}$ \\
\hline
\end{tabular}

From the table 4.2. above, it can be seen that the students had grammatical errors in changing active voice to passive voice based on Surface Strategy Taxonomy categories. In the Omission Category their total number of errors was 56 (20.22 \%). In Addition Category the students' total number of errors was $28(10.11 \%)$. In Misformation Category the students' total number of errors was $168(60.65 \%)$, and the last in Misordering Category the students' total number of errors was $25(9.03 \%)$.

\section{Discussion}

Based on data analysis, researchers found that the total errors made by students were 277 . The types of errors students made were ommission (56 or 20.22\%), misformation (168 or $60.65 \%$ ), addition (28 or $10.11 \%$ ) and misordering (25 or $9.03 \%$ ). The data also shows that the mistake of the second grade students of SMP YPI Amir Hamzah Medan in changing passive sentences into active sentences which is mostly done by students is misformation. The type of student error that students do the least in changing active voice into passive voice is misordering. So, the dominant types errors on changing active voice into passive voice is misformation. 


\section{CONCLUSION AND SUGESTION}

\section{Conclusion}

Based on the analysis of changing active voice to passive voice on the 24 of students at the eighth grade SMP YPI Amir Hamzah Medan, it was found that there are many types of students' grammmarical errors in changing active voice to passive voice they are: Omissions, Additions, Misformations and Misordering types.

In the Omission Category their total number of errors was 56 (20.22 \%). In Addition Category the students' total number of errors was $28(10.11 \%)$. In Misformation Category the students' total number of errors was $168(60.65 \%)$, and the last in Misordering Category the students' total number of errors was $25(9.03 \%)$

The data also shows that the mistake of the eighth grade students of SMP YPI Amir Hamzah Medan in changing active voice into passive voice which is mostly done by students is misformation. The type of student error that students do the least in changing active voice into passive voice is misordering. So, the dominant types errors on changing active voice into passive voice is misformation.

Sugestion

In this part, the writer would like to serve some suggestion and hopefully they are useful for the students and the teacher, namely:

1. The students have to pay attention to the teachers' explanation about in changing active voice into passive voice.

2. The students should read any kind of grammar book to enrich their ability in changing active voice into passive voice.

3. The teacher should give detailed and clear explanation to the students about the form of changing active voice into passive voice.

4. The teacher should be creative to use method of teaching.

\section{REFERENCES}

Bernhardt, M. (2013). Washington Irving's western adventure: Masculinity, race, and the early American frontier. Journal of the West, 52(1), 17-24.

Allwright, Dick and Bailey, Kathleen M. 2000. Focus on the Language Classroom. Cambridge: Cambridge University Press.

Azar, Betty Schrampfer. 2001. Fundamental of English Grammar. New Jeresey: Prentice Hall. Inc.

Brown, H. Douglas. 1999. Principles a Language Learning and Teaching. New Jeresey: Prentice Hall. Inc.

Corder, S. Pit. 1973. Introducing Applied Lingistic. England Pingiun Book.

Dulay, H., Burt. M. \& Krashen S. 1982. Language Two, Oxford : Oxford University Press.

Ellis, Rod. 1994. The Study of Second Language Acquisition. Oxford : Oxford University Press.

Qodir, Abdul (2006). Error Analysis on Changing Active Voice Into Passive Voice. HIMMAH Vol.VII. January, 18th 2006

Richards, Jack. C. 1974. Errors Analyses : Perpective on Second Language Acquisition. London: Longman Group Limited.

Richards, Jack, John Platt, and Heidi Weber. 1985.Longman dictionary of applied linguistics. Harlow, Essex, England: Longman.

Werner, Patricia, Nelson John. 2007. Mosaic Grammar 2. New York: TheMcGraw-Hill 9 